\title{
KEBIJAKAN PENGENTASAN KEMISKINAN DI KAWASAN PERDESAAN MELALUI USAHA BUDIDAYA PERIKANAN DI KABUPATEN MALANG
}

\author{
Wawan Oktariza ${ }^{1)}$, Anggraini Sukmawati'2) \\ ${ }^{1)}$ Fakultas Perikanan dan IImu Kelautan IPB; ${ }^{2)}$ Fakultas Ekonomi dan Manajemen IPB \\ Email : wawanok@ipb.ac.id; wawanoktariza11@gmail.com
}

\begin{abstract}
Abstrak
Kabupaten Malang memiliki potensi perikanan budidaya yang cukup besar. Produksi perikanan budidaya daerah ini tahun 2016 mencapai mencapai $20,562.55$ ton. Komoditas utama budidaya yaitu ikan lele dan nila dengan produksi masing-masing 9,593.97 ton dan 8,940,13. Jenis usaha budidaya yang dikembangkan meliputi budidaya pembenihan, budidaya pendederan dan budidaya pembesaran. Pengembangan usaha perikanan budidaya di kawasan pedesaan di kabupaten ini dijadikan salah satu upaya pengentasan kemiskinan. Tujuan kajian ini yaitu untuk menganalisis kebijakan pengentasan kemiskinan di kawasan perdesaan melalui pengembangan usaha budidaya perikanan di Kabupaten Malang. Metode analisis kajian ini menggunakan analisis hierarki proses (AHP) dengan menggunakan perangkat lunak expert choice 2000. Dari hasil analisis diketahui bahwa usaha budidaya pembesaran merupakan alternatif kebijakan prioritas dengan bobot 0,402 ; alternatif kebijakan kedua usaha budidaya pembenihan $(0,357)$ dan ketiga usaha pendederan $(0,239)$. Hal ini karena usaha budidaya pembesaran memberikan tingkat pendapatan yang relatif lebih tinggi dibanding usaha pembenihan dan pendederan. Satu hal yang harus diperhatikan apabila alternatif kebijakan ini diterapkan yaitu perlu bantuan modal yang lebih besar karena usaha pembesaran memerlukan modal usaha yang lebih besar dibanding usaha pembenihan dan pendederan.
\end{abstract}

Kata Kunci : budidaya perikanan, pengentasan kemiskinan, Kabupaten Malang, analisis hierarki proses

\section{PENDAHULUAN}

Potensi perikanan Kabupaten Malang terdiri dari potensi perikanan budidaya dan perikanan tangkap. Potensi perikanan budidaya antara lain budidaya perairan umum, mina padi, mina mendong, kolam, budidaya air payau dan budidaya laut. Dari data diketahui potensi budidaya perairan umum antara lain berada di Kecamatan Kalipare, Pagak, Sumberpucung, Kromengan, Ngantang, dan Pagelaran. Potensi budidaya mina padi antara lain berada di Kecamatan Wajak, Turen, Bululawang, Gondanglegi, Ngajum, Wonosari, Tajinan, dan Pakis. Potensi mina mendong ada di Kecamatan Wajak. Potensi budidaya kolam tersebar di seluruh kecamatan. Potensi budidaya tambak berada di Kecamatan Gedangan, Sumbermanjing Wetan dan Tirtoyudo. Potensi budidaya laut berada di Kecamatan Donomulyo, Gedangan, Bantur, Sumbermanjing Wetan, Tirtoyudo, dan Ampelgading.

Potensi luas lahan budidaya perikanan di daerah ini mencapai 20,521.4 ha. Pada sisi lahan tingkat pemanfaatannya pada tahun 2016 baru mencapai 516.64 
ha atau $2.52 \%$ dari potensi yang tersedia. Berikut ini disajikan potensi dan luas lahan budidaya menurut jenis budidaya di Kabupaten Malang tahun 2016.

Tabel 1. Potensi dan pemanfaatan lahan budidaya perikanan tahun 2016

\begin{tabular}{|c|c|c|c|}
\hline Jenis budidaya & Potensi (ha) & $\begin{array}{l}\text { Luas lahan } \\
\text { (ha) }\end{array}$ & $\begin{array}{c}\text { Pemanfaatan } \\
(\%)\end{array}$ \\
\hline Tambak & 186 & 84.5 & 45.43 \\
\hline Kolam & 4,418 & 195.5 & 4.42 \\
\hline Minapadi & 12,882 & 12.0 & 0.001 \\
\hline Minamendong & 180 & 33.0 & 18.33 \\
\hline $\begin{array}{l}\text { Perairan umum (jaring } \\
\text { apung) }\end{array}$ & 2,326 & 191.6 & 8.24 \\
\hline Budidaya laut & 530 & 0.0 & 0.00 \\
\hline Jumlah & 20,521 & 516.6 & 2.52 \\
\hline
\end{tabular}

Sumber: Dinas Kelautan dan Perikanan Kabupaten Malang (2017)

Produksi perikanan budidaya Kabupaten Malang tahun 2016 mencapai $20,562.55$ ton. Produksi budidaya sebagian besar berasal dari budidaya kolam yang mencapai 9,506.75 ton dan budidaya jaring apung 8,583.27 ton, sedang sisanya berasal dari budidaya tambak, minapadi dan minamendong. Komoditas unggulan perikanan budidaya daerah ini yaitu ikan nilai dan lele. Pada tahun 2016 produksi nila mencapai 8,940,13 ton dan lele 9,593.97 ton. Komoditas lainnya yaitu udang vannamei, ikan mas, gurame, patin dan lainnya.

Sebagian desa-desa yang ada di Kabupaten Malang termasuk ke dalam desa yang dihuni oleh penduduk yang termasuk dalam kelompok penduduk miskin. Berbagai upaya telah dilakukan oleh pemerintah, baik pemerintah pusat maupun pemerintah daerah, untuk mengurangi jumlah penduduk miskin. Salah satu upaya pengentasan kemiskinan di kawasan perdesaan di kabupaten ini dilakukan dengan melakukan pengembangan usaha budidaya perikanan. Hal ini dilakukan di Kecamatan Wajak melalui Program APP (Anti Poverty Programme) yang dilakukan oleh Pemerintah Provinsi Jawa Timur.

Anti Poverty Programme merupakan salah satu dari kebijakan percepatan Penanganan Kemiskinan di Jawa Timur. Tujuan Umum APP adalah penanganan penduduk miskin agar memiliki pendapatan dan daya beli, melalui pemberdayaan Usaha Kelompok Masyarakat miskin dengan pola kemitraan yang berbasis cluster.

Konsep dasar APP yaitu melakukan pemberdayaan usaha ekonomi produktif kelompok masyarakat miskin yang difasilitasi Pendampingan dan Mitra Usaha sebagai penampung/pembeli hasil produksi dari Kelompok Masyarakat (Pokmas). POKMAS mendapat bantuan sarana dan prasarana produksi yang bersifat hibah, selanjutknya menjadi aset Pokmas untuk dimanfaatkan oleh anggota dalam melaksanakan kegiatan usaha dan diwajibkan untuk melakukan perguliran dengan mekanisme sesuai kesepakatan anggota. Pemasaran produk yang dihasilkan Pokmas dapat dilakukan kepada mitra usaha dan atau pasar umum dengan tingkat harga yang layak.

Pengembangan usaha perikanan budidaya yang bertujuan untuk pengentasan kemiskinan di kawasan perdesaan memerlukan memerlukan kajian 
lebih mendalam. Hal ini karena usaha perikanan budidaya berdasarkan output terbagi menjadi tiga jenis yaitu budidaya pembenihan, budidaya pendederan, dan budidaya pembesaran. Ketiga jenis usaha ini memiliki karakteristik teknis dan ekonomi yang berbeda meskipun saling berhubungan. Tujuan kajian ini yaitu menganalisis strategi kebijakan pengembangan usaha budidaya perikanan dalam rangka pengentasan kemiskinan di kawasan pedesaan di Kabupaten Malang.

\section{METODE PENELITIAN}

\section{Waktu dan Tempat Penelitian}

Penelitian dilakukan di Kabupaten Malang, Provinsi Jawa Timur seperti terlihat pada Gambar 1. Penelitian dilaksanakan selama delapan bulan yaitu dari bulan Maret sampai bulan November 2017.

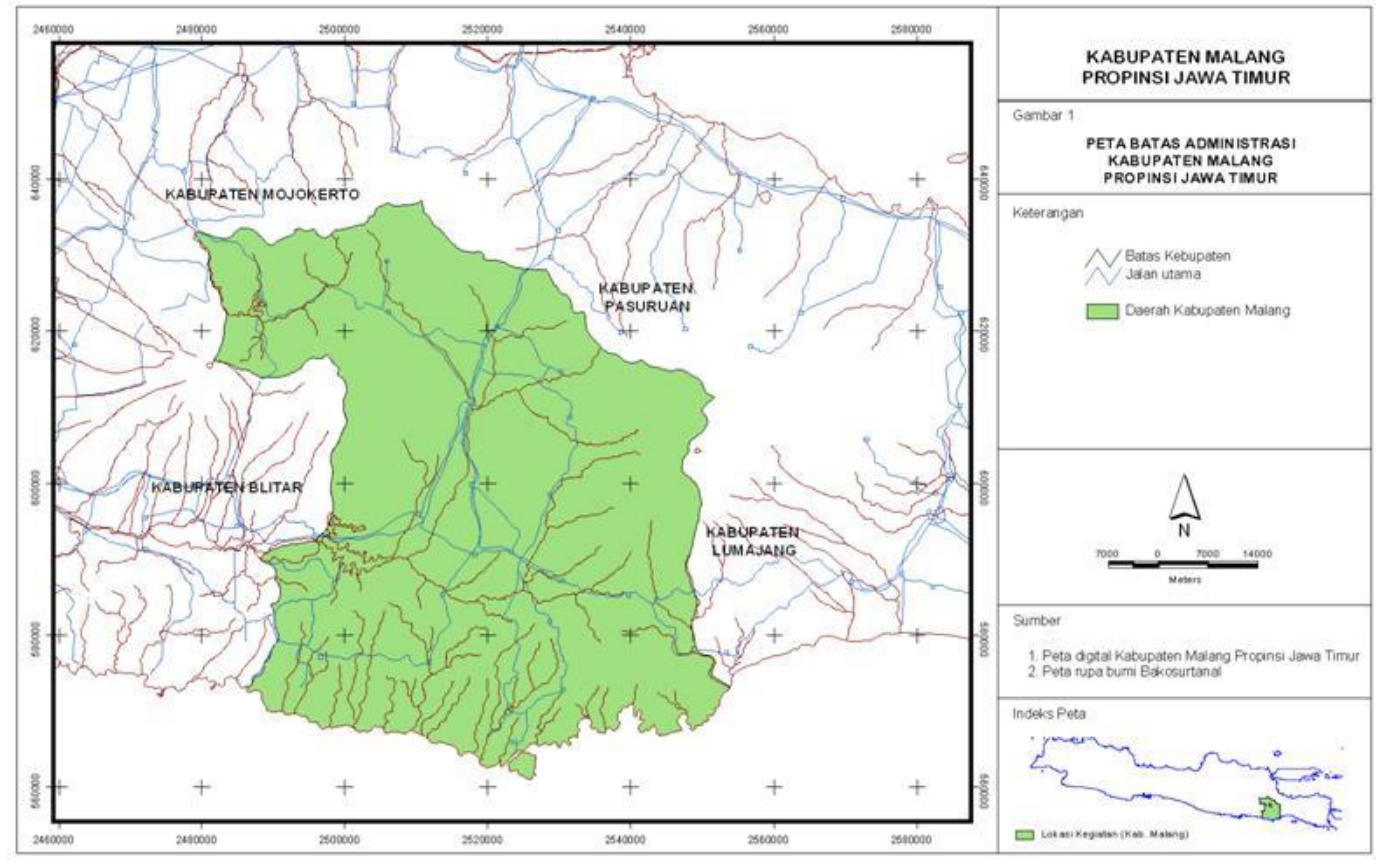

Gambar 1. Kabupaten Malang

(Sumber: Bappeda Kabupaten Malang 2016)

\section{Pengumpulan data}

Pengumpulan data dilakukan dengan beberapa metode yaitu observasi, wawancara, dan focus group discussion. Data yang dikumpulkan meliputi aspek teknis, dan sosial ekonomi. Data primer digunakan sebagai informasi terkait situasi problematis terkait penyediaan SDM dan pembobotan prioritas strategi berdasarkan preferensi atau tingkat kesukaan pakar. Data sekunder yang digunakan pada penelitian ini berasal dari jurnal, website relevan, buku teks, laporan, dan penelitian ilmiah lainnya.

Penentuan responden dilakukan berdasarkan teknik purposive sampling dengan pertimbangan bahwa responden merupakan pelaku, baik individu maupun lembaga, yang mempengaruhi pengambilan kebijakan perikanan. Responden untuk penyusunan alternatif kebijakan melibatkan 11 orang responden yang terdiri 
dari pemangku kepentingan bidang perikanan yaitu Badan Perencanaan Pembangunan Daerah (BAPPEDA), Dinas Kelautan dan Perikanan, Balai Benih Ikan, Penyuluh Perikanan, pelaku usaha perikanan yang meliputi pembudidaya pembesaran, Unit Pembenihan Rakyat (UPR), pedagang ikan dan pemasok pakan.

Responden penelitian terdiri atas orang-orang yang terlatih dengan baik dan kompeten dengan pengetahuan yang berkaitan dengan spesialiasi area isu target. Saaty and Vargas (2012), menyatakan bahwa responden penelitian dengan metode AHP meliputi :

1. Pengambil keputusan dari kalangan top management.

2. Para ahli dari berbagai latar belakang fungsional yang memiliki ide terkait tugas-tugas yang diberikan di masing-masing fungsi.

3. Pimpinan atau anggota divisi SDM perusahaan atau industri.

\section{Analisis Data}

Analisis kebijakan pengentasan kemiskinan untuk pelaku usaha budidaya perikanan dilakukan dengan menggunapan analitycal hierarchy process atau AHP. Metode AHP dirancang untuk menanggulangi pemilihan yang terbaik secara rasional dan intuitif dari sejumlah alternatif yang dievaluasi dengan beberapa kriteria (Saaty and Vargas 2012). Marimin et al. (2013) mengatakan bahwa AHP memiliki banyak keunggulan dalam menjelaskan proses pengambilan keputusan karena AHP digambarkan secara grafis sehingga mudah dipahami dan mampu menguraikan keputusan kompleks menjadi keputusan-keputusan kecil yang lebih sederhana.

Hierarki dibuat dengan menggunakan 5 tingkat yaitu: tingkat pertama yaitu fokus yang merupakan tujuan utama yaitu pengentasan kemiskinan di perdesaan melalui usaha budidaya perikanan; tingkat kedua faktor yang mempengaruhi usaha budidaya perikanan sehingga secara tidak langsung juga mempengaruhi upaya pengentasan kemiskinan; tingkat ketiga aktor yang terlibat dalam upaya pengentasan kemiskinan yang mencakup pembudidaya ikan, pemerintah, perguruan tinggi, pedagang pengumpul dan pemasok input produksi perikanan; tingkat keempat yaitu tujuan yang ingin dicapai untuk pengentasan kemiskinan; dan tingkat kelima yaitu alternatif kebijakan untuk mencapai upaya pengentasan kemiskinan. 


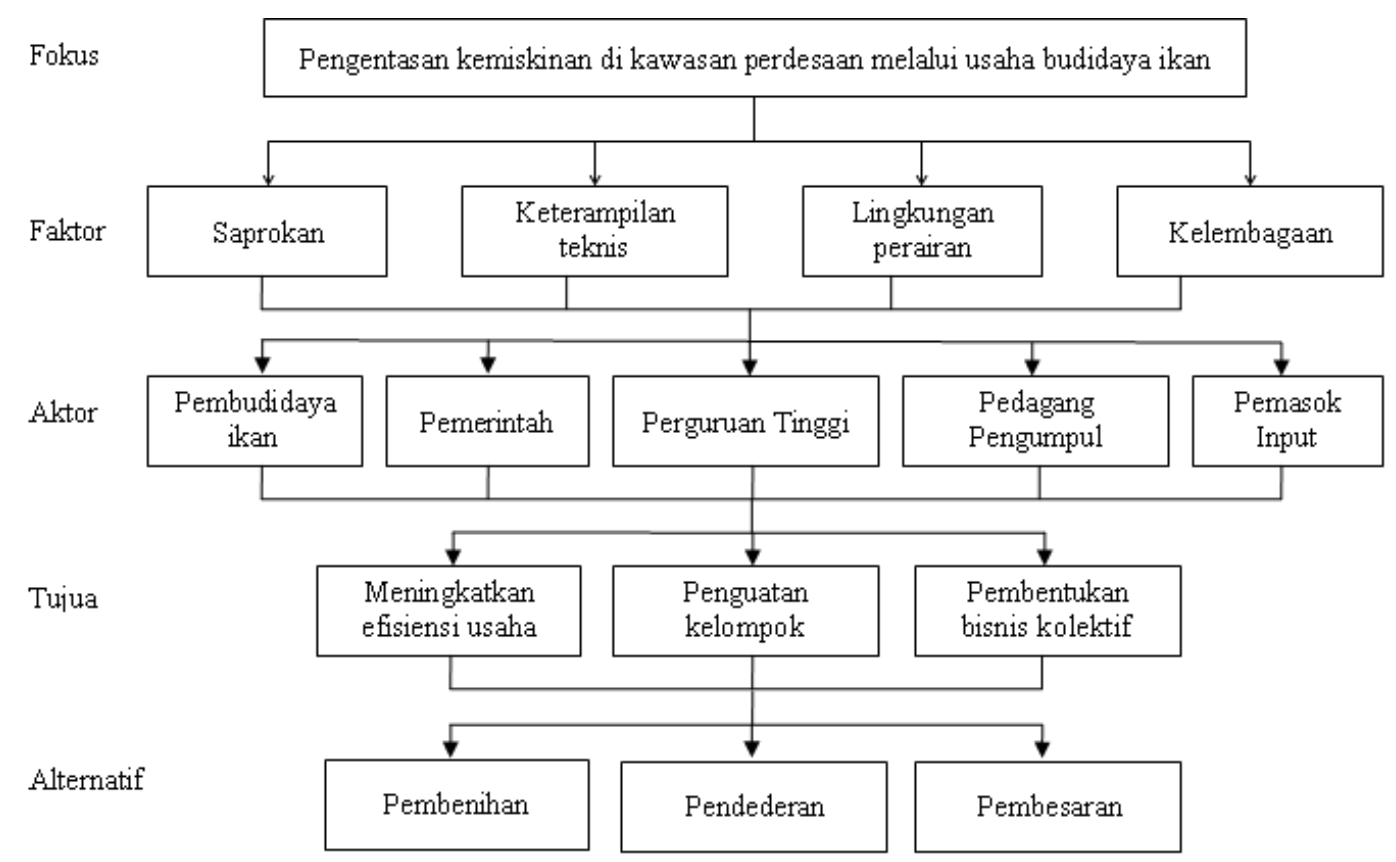

Gambar 2 Struktur hierarki AHP

Pemecahan masalah dalam AHP dilakukan dengan menggunakan perangkat lunak expert choice 2000 (Microsoft office 2000). Tahapan pemecahan masalah yang dilakukan dengan menggunakan metode AHP menurut Saaty (1990) yaitu sebagai berikut :

1)Mendefinisikan persoalan dan pemecahan yang akan dilakukan. Pada tahap ini dilakukan pengenalan, pemahaman dan penguasaan masalah secara mendalam.

2) Menyusun hierarki yang dimulai dengan tujuan, kriteria, dan alternatif tindakan. Selanjutnya berdasarkan hierarki tersebut disusun perumusan strategi kebijakan dengan menggunakan hierarki proses ke depan dan hierarki proses balik.

3) Membuat matrik banding berpasangan yang menggambarkan pengaruh setiap elemen yang relevan atas setiap kriteria setingkat diatasnya.

4) Melakukan perbandingan dan penilaian. Perbandingan berpasangan dilakukan dengan pembobotan masing-masing komponen.

\section{HASIL DAN PEMBAHASAN}

\section{Keragaan Perikanan Budidaya Kabupaten Malang}

Kabupaten Malang memiliki potensi perikanan budidaya yang cukup besar. Perikanan budidaya yang berkembang meliputi perikanan budidaya tambak, kolam, minapadi, mina mendong, perairan umum (jaring apung) dan budidaya laut. Potensi budidaya perairan umum antara lain berada di Kecamatan Kalipare, Pagak, Sumberpucung, Kromengan, Ngantang, dan Pagelaran. Potensi mina padi antara lain berada di Kecamatan Wajak, Turen, Bululawang, Gondanglegi, Ngajum, Wonosari, Tajinan, dan Pakis. Potensi mina mendong ada di Kecamatan Wajak. Potensi budidaya kolam tersebar di semua kecamatan se-wilayah 
Kabupaten Malang. Potensi tambak (budidaya air payau) berada di Kecamatan Gedangan, Sumbermanjing Wetan dan Tirtoyudo. Potensi budidaya laut berada di 6 (enam) kecamatan pantai yaitu Kecamatan Donomulyo, Gedangan, Bantur, Sumbermanjing Wetan, Tirtoyudo dan Ampelgading.

Produksi perikanan budidaya dari tahun ke tahun mengalami peningkatan. Pada tahun 2015 produksi mencapai $20.476,92$ ton atau meningkat sebesar $4,71 \%$ dibanding produksi tahun 2014. Pada tahun 2016 produksi perikanan budidaya mengalami kenaikan sebesar $0,42 \%$ atau sebesar 21.162 ton. Perkembangan produksi perikanan budidaya menurut jenis budidaya disajikan pada Tabel 2.

Tabel 2. Perkembangan produksi perikanan budidaya Kabupaten Malang 2015-2016

\begin{tabular}{lccc}
\hline \multicolumn{1}{c}{ Jenis budidaya } & $\mathbf{2 0 1 5}$ & $\mathbf{2 0 1 6}$ & $\begin{array}{c}\text { Pertumbuhan } \\
\text { (\%) }\end{array}$ \\
\hline Tambak & 2189.00 & 2357.28 & 7.96 \\
Kolam & 9416.97 & 9595.96 & 1.90 \\
Minapadi & 20.45 & 26.04 & 27.33 \\
Minamendong & 89.10 & 0.00 & $(100.00)$ \\
Perairan umum (jaring & 8761.40 & 8583.27 & $(2.03)$ \\
apung) & 0.00 & 0.00 & - \\
Budidaya laut & 20476.92 & 20562.55 & 0.42 \\
\hline Jumlah & &
\end{tabular}

Sumber: Dinas Kelautan dan Perikanan Kabupaten Malang (2017)

Seluruh kecamatan di Kabupaten Malang pada dasarnya memiliki lahan budidaya perikanan sehingga setiap kecamatan memberikan kontribusi terhadap produksi perikanan. Namun berdasar data diketahui sari 33 kecamatan, terdapat 6 kecamatan yang memiliki produksi perikanan budidaya yang lebih tinggi. Total produksi keenam kecamatan tersebut mencapai $59.69 \%$ dari total produksi Kabupaten Malang tahun 2016 yang mencapai 20562.55 ton. Produksi perikanan budidaya menurut kecamatan penghasil utama disajikan pada Tabel 3.

Tabel 3. Produksi perikanan budidaya tahun 2016 menurut kecamatan utama di Kabupaten Malang

\begin{tabular}{llc}
\hline \multicolumn{1}{c}{ Kecamatan } & Produksi (ton) & Share (\%) \\
\hline Sumberpucung & 3850.29 & 18.72 \\
Kalipare & 2291.40 & 11.14 \\
Pagak & 1872.01 & 9.10 \\
Kromengan & 1464.73 & 7.12 \\
Gedangan & 1815.46 & 8.83 \\
Wajak & 980.12 & 4.77 \\
Lain-lain & 8288.54 & 40.31 \\
\hline Jumlah & 20562.55 & 100.00 \\
\hline
\end{tabular}

Sumber: Dinas Kelautan dan Perikanan Kabupaten Malang (2017)

\section{Kebijakan Pengentasan Kemiskinan melalui Perikanan Budidaya}


Pengembangan usaha budidaya perikanan pada kegiatan Anti Poverty Programme (APP) di Kabupaten Malang memiliki tujuan untuk melakukan percepatan pengentasan kemiskinan diantaranya melalui pengembangan usaha budidaya perikanan. Faktor-faktor yang mempengaruhi upaya pengembangan usaha budidaya perikanan dibagi menjadi 4 faktor yaitu:

a) Saprokan (sarana produksi perikanan) adalah semua hal atau unsur yang dibutuhkan atau dengan kata lain disebut juga bahan baku dalam pengelolaan produksi perikanan, termasuk bibit, pakan, dan obat-obatan ternak.

b) Keterampilan teknis adalah kecakapan atau kemampuan yang dimiliki oleh pembudidaya ikan untuk melaksanakan tugas atau pekerjaan di dalam suatu organisasi.

c) Lingkungan perairan adalah kondisi lingkungan perairan dimana kegiatan budidaya ikan dilakukan yang dapat mempengaruhi proses pemeliharaan ikan mulai dari persiapan hingga panen.

d) Kelembagaan adalah suatu jaringan yang terdiri dari sejumlah orang dan lembaga untuk tujuan tertentu, memiliki aturan dan norma, serta memiliki struktur.

Kebijakan pengentasan kemiskinan untuk pelaku usaha budidaya perikanan melalui Program APP dianalisis dengan menggunakan analisis hierarki proses (AHP). Hierarki dibuat dengan menggunakan 5 tingkat yaitu tingkat pertama yaitu fokus yang merupakan tujuan utama yaitu pengentasan kemiskinan di perdesaan melalui usaha budidaya perikanan; tingkat kedua faktor yang mempengaruhi usaha budidaya perikanan sehingga secara tidak langsung juga mempengaruhi upaya pengentasan kemiskinan; tingkat ketiga aktor yang terlibat dalam upaya pengentasan kemiskinan yang mencakup pembudidaya ikan, pemerintah, perguruan tinggi, pedagang pengumpul dan pemasok input produksi perikanan; tingkat keempat yaitu tujuan yang ingin dicapai untuk pengentasan kemiskinan; dan tingkat kelima yaitu alternatif kebijakan untuk mencapai upaya pengentasan kemiskinan.

Hasil pengolahan AHP kebijakan pengentasan kemiskinan di kawasan perdesaan melalui usaha budidaya perikanan di Kabupaten Malang dengan menggunakan software expert choice disajikan pada Gambar 3. 


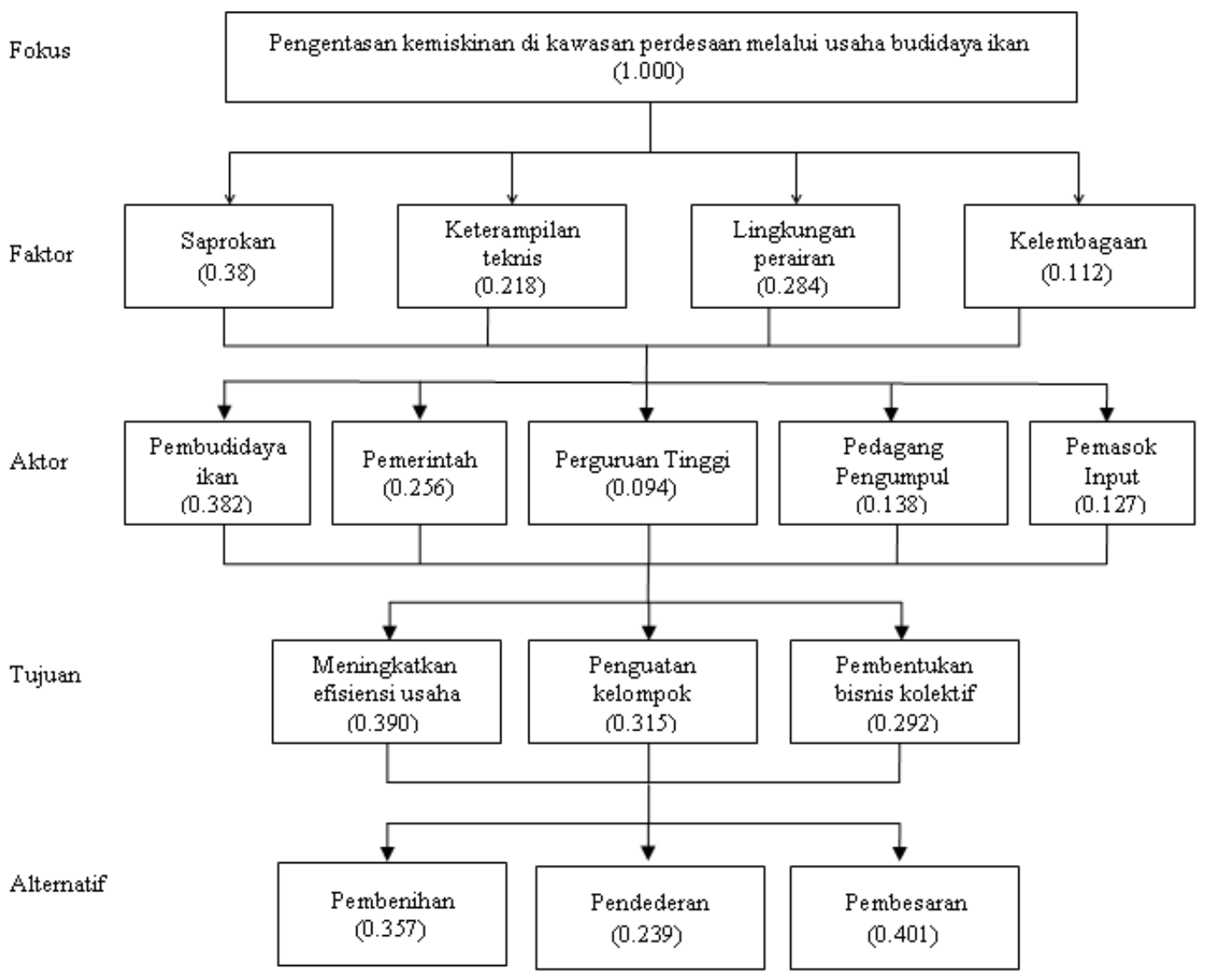

Gambar 3. Diagram kebijakan pengentasan kemiskinan di kawasan pedesaan melalui usaha budidaya perikanan di Kabupaten Malang

Berdasarkan pengolahan data kuesioner AHP dengan menggunakan aplikasi expert choice, analisis tujuan diperoleh urutan sebagai berikut: meningkatkan efisiensi usaha (0.390), penguatan kelompok (0.315), dan pembentukan bisnis kolektif (0.292). Alternatif kebijakan diperoleh urutan sebagai berikut: pembesaran (0.401), pembenihan (0.357), dan pendederan $(0.239)$.

\section{Hasil Pengolahan Elemen Faktor}

Berdasarkam hasil pengolahan diketahui bahwa faktor sarana produksi perikanan menempati urutan pertama prioritas dengan bobot 0,385 , faktor lingkungan perairan menempati urutan kedua, keterampilan teknis ketiga dan keempat faktor kelembagaan. Hasil analisis AHP untuk analisis elemen faktor disajikan pada Tabel 4.

Tabel 4. Bobot nilai analisis elemen faktor

\begin{tabular}{lc}
\hline \multicolumn{1}{c}{ Faktor } & Bobot nilai \\
\hline Sarana produksi perikanan & 0.385 \\
Keterampilan teknis & 0.218 \\
Lingkungan perairan & 0.284 \\
Kelembagaan & 0.112 \\
\hline
\end{tabular}


Ketersediaan sarana produksi perikanan merupakan faktor yang harus ada untuk memulai usaha budidaya perikanan. Sarana produksi perikanan yang meliputi kolam atau wadah budidaya. peralatan produksi dan lainnya merupakan syarat mutlak yang harus tersedia. Faktor kelembagaan memiliki nilai terendah diduga karena belum adanya lembaga pembudidaya yang memiliki peran yang kuat dalam usaha perikanan di daerah ini.

\section{Hasil Pengolahan Elemen Aktor}

Dari hasil analisis elemen aktor diperoleh urutan nilai sebagai berikut: pembudidaya ikan (0.382). pemerintah (0.256). pedagang pengumpul (0.139). pemasok input (0.127). dan perguruan tinggi (0.094). Secara lengkap nilai analisis elemen aktor terhadap faktor disajikan pada Tabel 5.

Tabel 5. Bobot nilai analisis elemen aktor terhadap faktor

\begin{tabular}{|c|c|c|c|c|c|c|}
\hline \multirow[b]{2}{*}{ Aktor } & \multicolumn{4}{|c|}{ Terhadap factor } & \multirow{2}{*}{$\begin{array}{l}\text { Bobot } \\
\text { faktor }\end{array}$} & \multirow{2}{*}{$\begin{array}{l}\text { Bobo } \\
\text { aktor }\end{array}$} \\
\hline & Saprokan & $\begin{array}{c}\text { Keterampilan } \\
\text { teknis }\end{array}$ & $\begin{array}{c}\text { Lingkungan } \\
\text { perairan }\end{array}$ & Kelembagaan & & \\
\hline Pembudidaya Ikan & 0.336 & 0.456 & 0.400 & 0.357 & 0.385 & 0.382 \\
\hline Pemerintah & 0.221 & 0.237 & 0.267 & 0.390 & 0.218 & 0.256 \\
\hline Perguruan Tinggi & 0.060 & 0.117 & 0.121 & 0.102 & 0.284 & 0.094 \\
\hline $\begin{array}{l}\text { Pedagang } \\
\text { Pengumpul }\end{array}$ & 0.216 & 0.091 & 0.096 & 0.075 & 0.112 & 0.139 \\
\hline Pemasok Input & 0.167 & 0.098 & 0.116 & 0.077 & & 0.127 \\
\hline
\end{tabular}

Analisis Aktor terhadap faktor menunjukan hasil bahwa pembudidaya ikan lebih prioritas dibandingkan dengan aktor lainnya dengan bobot 0.382. Para pembudidaya ikan melihat bahwa hampir seluruh faktor. yang mencakup sarana produksi perikanan. keterampilan teknis. lingkungan perairan dan kelembagaan merupakan faktor yang penting sehingga mereka memberi bobot yang tinggi terhadap keempat faktor tersebut.

Perguruan tinggi memiliki bobot yang terendah terhadap elemen faktor yaitu 0.094. Hal ini diduga karena masih minimnya peran dan keterlibatan perguruan tinggi yang ada di kawasan Kabupaten Malang dan Kota Malang dalam pengembangan usaha budidaya perikanan. Berdasar informasi dari pelaku usaha budidaya perikanan diketahui bahwa memang ada keterlibatan dan peran beberapa perguruan tinggi dalam diseminasi teknologi dan informasi budidaya. namun intensitasnya dirasakan relatif rendah.

\section{Hasil Pengolahan Elemen Tujuan}

Dari hasil analisis elemen tujuan terhadap aktor menunjukan hasil bahwa efisiensi usaha merupakan tujuan prioritas pertama dibandingkan dengan tujuan lainnya dengan bobot 0.391 . Tujuan prioritas kedua yaitu penguatan kelompok (0.315) dan prioritas ketiga yaitu penguatan bisnis kolektif (0.292). Secara lengkap nilai analisis elemen tujuan terhadap aktor disajikan pada Tabel 6. 
Tabel 6. Bobot nilai analisis elemen tujuan terhadap aktor

\begin{tabular}{|c|c|c|c|c|c|c|c|}
\hline \multirow{2}{*}{ Tujuan } & \multicolumn{5}{|c|}{ Terhadap aktor } & \multirow{2}{*}{$\begin{array}{l}\text { Bobot } \\
\text { Aktor }\end{array}$} & \multirow{2}{*}{$\begin{array}{l}\text { Bobot } \\
\text { Tujuan }\end{array}$} \\
\hline & $\begin{array}{c}\text { Pembudidaya } \\
\text { Ikan }\end{array}$ & Pemerintah & $\begin{array}{c}\text { Perguruan } \\
\text { Tinggi }\end{array}$ & $\begin{array}{l}\text { Pedagang } \\
\text { Pengumpul }\end{array}$ & $\begin{array}{c}\text { Pemasok } \\
\text { Input }\end{array}$ & & \\
\hline $\begin{array}{l}\text { Efisiensi } \\
\text { usaha }\end{array}$ & 0.496 & 0.255 & 0.547 & 0.305 & 0.330 & 0.382 & 0.391 \\
\hline $\begin{array}{l}\text { Penguatan } \\
\text { kelompok }\end{array}$ & 0.254 & 0.541 & 0.210 & 0.202 & 0.250 & 0.256 & 0.315 \\
\hline $\begin{array}{l}\text { Bisnis } \\
\text { kolektif }\end{array}$ & 0.250 & 0.204 & 0.242 & 0.493 & 0.419 & 0.094 & 0.292 \\
\hline
\end{tabular}

Efisiensi usaha merupakan salah satu faktor yang akan mempengaruhi tingkat pendapatan usaha. Jika efisiensi usaha bagus maka tingkat pendapatan akan relatif lebih tinggi. Oleh karena efisiensi usaha merupakan tujuan prioritas pertama dibanding dengan kedua tujuan lainnya yaitu penguatan kelompok dan bisnis kolektif.

\section{Hasil Pengolahan Elemen Alternatif Kebijakan}

Dari hasil analisis elemen alternatif terhadap tujuan menunjukan hasil bahwa usaha pembesaran merupakan alternatif kebijakan prioritas dibandingkan dengan alternatif lainnya dengan bobot 0.402 . Alternatif kebijakan kedua yaitu usaha pembenihan (0.357) dan ketiga usaha pendederan (0.239). Secara lengkap nilai analisis elemen alternatif kebijakan terhadap tujuan disajikan pada Tabel 7.

Tabel 7. Bobot nilai analisis elemen alternatif terhadap tujuan

\begin{tabular}{|c|c|c|c|c|c|}
\hline \multirow[b]{2}{*}{ Alternatif } & \multicolumn{3}{|c|}{ Terhadap tujuan } & \multirow{2}{*}{$\begin{array}{l}\text { Bobot } \\
\text { tujuan }\end{array}$} & \multirow{2}{*}{$\begin{array}{l}\text { Bobot } \\
\text { alternatif }\end{array}$} \\
\hline & $\begin{array}{c}\text { Efisiensi } \\
\text { usaha }\end{array}$ & $\begin{array}{l}\text { Penguatan } \\
\text { kelompok }\end{array}$ & $\begin{array}{c}\text { Bisnis } \\
\text { kolektif }\end{array}$ & & \\
\hline Pembenihan & 0.396 & 0.446 & 0.212 & 0.391 & 0.357 \\
\hline Pendederan & 0.293 & 0.165 & 0.249 & 0.315 & 0.239 \\
\hline Pembesaran & 0.311 & 0.389 & 0.539 & 0.292 & 0.402 \\
\hline
\end{tabular}

Usaha budidaya pembesaran ikan umumnya memberikan tingkat pendapatan yang relatif lebih tinggi dibanding usaha budidaya pendederan dan pembenihan. Oleh karena itu alternatif kebijakan usaha budidaya pembesaran merupakan prioritas pertama dibanding kedua jenis usaha budidaya lainnya. Namun satu hal yang harus diperhatikan apabila alternatif kebijakan ini akan diterapkan yaitu bahwa untuk usaha budidaya pembesaran memerlukan modal usaha yang relatif lebih besar dibanding usaha pembenihan dan pendederan.

\section{KESIMPULAN DAN REKOMENDASI}


Perikanan budidaya belum dikembangkan secara optimal di Kabupaten Malang. Hal ini terlihat dari pemanfaatan potensi lahan budidaya yang baru $2.52 \%$ dari total potensi lahan seluas 20.521 ha. Terdapat 6 kecamatan yang memiliki kontribusi perikanan budidaya terbesar yaitu Kecamatan Sumberpucung. Kalipare. Pagak. Kromengan. Gedangan dan Wajak. Kontribusi produksi perikanan budidaya ke 6 kecamatan tersebut mencapai 59.69\% dari total produksi tahun 2016 yang mencapai 20562.55 ton.

Usaha budidaya pembesaran merupakan alternatif kebijakan prioritas yang perlu dikembangkan dalam rangka pengentasan kemiskinan di Kabupaten Malang. Alternatif kebijakan ini memiliki bobot 0.402. Alternatif kebijakan kedua dan ketiga yaitu masing-masing usaha pembenihan (0.357) dan usaha pendederan (0.239). Hal ini karena usaha pembesaran ikan memberikan tingkat pendapatan yang relatif lebih besar dibandingkan usaha pembenihan dan pendederan.

Usaha pembesaran ikan memerlukan modal yang lebih besar dibandingkan usaha pembenihan dan pendederan. Oleh karena itu jika alternatif usaha pembesaran yang dijadikan pilihan kebijakan maka diperlukan adanya kerjasama dengan perbankan untuk menyediakan kredit dengan suku bunga lebih rendah daripada pinjaman komersial.

\section{DAFTAR PUSTAKA}

Badan Perencanaan Pembangunan Daerah Kabupaten Malang. 2015. Anti Poverty Program (APP) Kabupaten Malang Tahun 2015. Badan Perencanaan Pembangunan Daerah Kabupaten Malang. Kepanjen Malang.

Dinas Kelautan dan Perikanan Kabupaten Malang. 2009. Masterplan Pengembangan Kawasan Minapolitan Kabupaten Malang. Dinas Kelautan dan Perikanan Kabupa-ten Malang. Kepanjen - Malang.

Dinas Kelautan dan Perikanan Kabupaten Malang. 2017. Buku Statistik Kelautan dan Perikanan Kabupaten Malang Tahun 2016. Dinas Kelautan dan Perikanan Kabupa-ten Malang. Kepanjen - Malang.

Marimin. Taufik D. Suharjito. Syarief H. Ditdit NU. Retno A. Sri M. 2003. Teknik dan Analisis Pengambilan Keputusan Fuzzy dalam Manajemen Rantai Pasok. IPB Press. Bogor.

Saaty TL. 1990. How to Structure a Decision Problem: An Analytical Hierarchy Process Perspective. RWS Publication. Pittsburgh.

Saaty TL. Vargas LG. 2012. Models. Methods. Concepts and Applications of the Analytic Hierarchy Process. Springer Science \& Business Media. New York.

Sukmawati A. Oktariza W. Sjaf S. 2017. Kajian Kebijakan Pembangunan Daerah Bidang Peternakan dan Perikanan sebagai Upaya Pengentasan Kemiskinan. Laporan Penelitian Institusi. Institut Pertanian Bogor. Bogor. 